\title{
ОСВІТА — КОМУ І НАВІЩО?
}

\author{
Л. М. Трусей, А. О. Мироненко
}

Викладачі Харківського національного університету Повітряних Сил імені Івана Кожедуба

Навчати народ - значить робити його кращчим; просвіщзати — значить підвищувати його моральність; опанувати грамоту - значить оволодіти культурою.

(В. Гюго)

Освіта — це основа суспільного прогресу, який цілком залежить від іiі якості, а не від кількості навчальних закладів. Від якості освіти залежить економічний, культурний, інтелектуальний і духовний розвиток країни. Філософи, соціологи, представники різних галузей гуманітарного та природничо-наукового знання пов'язують розвиток економіки із саморозвитком, самоактуалізацією, самовдосконаленням особистості, що, в свою чергу, зумовлюється якістю освіти.

Донедавна суспільство цілком задовольняла так звана класична модель освіти, зорієнтована в основному на засвоєння та передачу наукових, однозначно інтерпретованих знань, i, на жаль, вона продовжує залишатися провідною в багатьох вузах країни. Сьогодні вона піддається критиці як така, що не відповідає сучасним вимогам, сучасним викликам, що потребує впровадження нових технологій, нових стратегій розвитку, які формуються на основі сучасних знань, нової інформації, зв’язаної з високоефективними технологіями. Для більшості закладів такі вимоги залишаються складною проблемою.

Стрімке зростання масиву знань поставило сучасну систему освіти перед вибором: або пізнати за короткий проміжок часу великий обсяг навчального матеріалу, щоправда фрагментарно, або приділити увагу окремим наукам, однак змістовно і систематично. Будь-який варіант недосконалий: перший відтворюватиме дилетантську ерудицію, другий — вузькоспеціальні знання.

Пошуками інноваційних моделей якісної освіти та питаннями смислу освіти, як суспільного явища, займаються представники соціальної філософії, соціології освіти, педагогіки, філософії освіти тощо. Питання, поставлені Кантом, актуальні і сьогодні: що я можу знати? Що я маю робити? На що я можу сподіватися? [1]. Вони постають і перед викладачем і перед студентом. Що робити з отриманим знанням (дипломом), якщо за час добування класичної освіти в престижному вузі, по закінченню якого знання застарівають. Філософське дослідження феномену та потенціалу освітньої інформаційної політики має, на наш погляд, відповідати сучасним викликам інформаційного суспільства. Слід шукати адекватні відповіді на них, тобто наукове обгрунтування. Інформаційні детермінанти новітніх освітніх явищ і процесів потребують розширення горизонтів практичної реалізації потенційних можливостей освіти, особливо в період поступового входження в європейський і світовий освітній простір. Однак, слід зберегти також і десятиліттями набутий освітянський досвід, використовуючи кращі зразки методів та методологій у навчальній діяльності.

Так звані цінності європейської техногенної цивілізації виявилися недосконалими, тому що світ опинився в критичній ситуації, яка потребує невідкладного пошуку нових шляхів розв'язання глобальних проблем для виживання людства. Про критичну ситуацію в царині освіти було заявлено ще в 1967 р. в підсумковій доповіді Джеймса Перкінса на міжнародній конференції в США з питань світової кризи освіти. Автор наголошував на «нездатності освіти йти в ногу з розвитком суспільства», а також на «невідповідності між сподіваннями окремих осіб і потребами суспільства, з одного боку, і можливостями системи освіти, з іншого» [2]. Причиною кризи освіти автор вважав недостатність ії креативного потенціалу. Креативний потенціал, або креативний підхід до освіти - це пошук нових напрямків розвитку, нових процесів, нових шляхів. Найважливіше - це зв'язок між креативністю та інноваціями, оскільки креативність передбачає продуктивне вирішення творчих завдань, а інновація — це реалізація найбільш життєздатних і конкурентоспроможних ідей. Таким чином, освіта повинна йти в ногу з потребами виробництва, не нехтуючи водночас завданнями всебічного розвитку особи.

I дійсно, за експертними оцінками фахівців, ключ до подолання кризової ситуації лежить в площині освіти, причому, шлях до їі вирішення має бути коротким, тому що нереалізовані можливості можуть не лише ускладнити ситуацію, а привести до катастрофічних наслідків. Саме тому освіта повинна виконувати не тільки традиційну функцію збереження та передачі соціального досвіду, а й більш важливу нині - випереджальну, превентивну функцію, готуючи людину до життя в епоху глобальних криз і непередбачуваних наслідків. Тому, потреба в дослідженні сутності, змісту, структури і функцій освіти — це найактуальніші завдання на сьогодні.

Утім, навіть за наявності великої кількості наукових джерел важко провести цілісне дослідження. Аналіз наукових джерел і публікацій засвідчує неоднозначне бачення проблем покращення освіти, акцентуючи увагу, в основному, на її недосконалості. XXI століття загострило проблему взаємної адаптації освіти і суспільства. 
Інтеграція України у європейський освітній простір вимагає вдосконалення національної освіти, пошуку дієвих шляхів підвищення її якості, впровадження інноваційних технологій в освітню діяльність, а також забезпечення безперервності освіти протягом усього життя. Сучасні глобальні проблеми вимагають професійної компетентності, критичного мислення, високої мобільності, здатності до адаптації в сучасних умовах життя. А тому вищій освіті необхідна радикальна та комплексна реформа, з ефективним використанням інформаційно-комунікаційних технологій у навчальному процесі, які стануть в майбутньому ефективним джерелом економічного зростання. Загальновідомо, що найкраща інвестиція в майбутнє країни — це якісна освіта. Саме вона спроможна дати набагато більший ефект за наявності кваліфікованих кадрів, здатних швидко й ефективно освоювати нові знання та уміння у науковому й інноваційному середовищі.

Адекватне вимогам часу інноваційне середовище можливе лише за умов високого рівня розвитку освітньої наукової системи. Саме тому проблема реформування - це першочергове завдання, спроможне привести освіту у відповідність до запитів економіки та інтеграції в єдиний європейський освітній простір, а також до піднесення дослідницьких та інноваційних технологій, таких як оптимізація виробничих процесів, інтеграція у виробництво нових технологій, виробів та видів послуг тощо.

Система вищої освіти має бути спрямованою на підготовку національної еліти, здатної виконувати не лише професійні та важливі соціальні функції, а також нести моральну відповідальність за державу, суспільство, за власну сферу діяльності. Відомо, що еліта не виникає сама собою або внаслідок неприродних подій. Підготовка національної еліти - результат тривалої роботи громадянського суспільства - змін законодавства та Конституції, громадянської люстрації, конфіскації нелегітимних багатств тощо [3]. Селекція еліти - процес довгий, конфліктний і технологічно складний. Україна має шанс виховати свою еліту, проте сьогодні замість національної еліти вона має олігархічний правлячий клас, далекий від інтересів та запитів власного народу, нездатний до морального самооновлення і самовдосконалення. Сучасний правлячий клас не можна назвати елітою, i сама дефініція «еліта» сприймається обивателем упредмечено, як, скажімо, елітні будинки — цілі домашні храми, елітна нерухомість або колекція земельних ділянок — все те, що захищено депутатським імунітетом.

Виходить, що, з одного боку, покладання на сучасну освіту, як на єдиний рятівний засіб, який здатен виплекати, виховати, виростити, сформувати національну еліту, яка в майбутньому спроможеться на радикальні універсальні глобальні політичні, економічні та соціальні зміни для всіх прошарків, — можна вважати утопією, умовою, що не відповідає викликам часу. Більш того, інколи здається, що зусилля «реформаторів» системи освіти спрямовані скоріш на ії затуплення, аніж на розвиток. Причому, песимістичні висновки аналітиків тримаються на загальновідомій істині: щоб знищити націю - потрібно знизити рівень освіти. Відомо також, що низький рівень освіти в Україні рано чи пізно може вбити ії як систему, що призведе не лише до національного занепаду, а й до загальної деградації суспільства, яке характеризується відсутністю моралі, честі, совісті, патріотизму, духовних цінностей, перетворюючи людину на агресивну, пусту, аморальну, бездушну істоту. Саме таке «перетворення» сприяє корупції у вищих ешелонах влади, що призводить лише до погіршення ситуації. В свою чергу, до відтоку професійних кадрів, тобто, втрати розумних людей, без яких побудувати успішну державу неможливо. Освіта, як вона організована в даний час в Україні, не робить людину ані більш моральною, ані більш щасливою і не змінює ні ії інстинкти, ні успадковані нею установки щодо поведінки, способу мислення тощо. Зазначимо, що подібні песимістичні висновки науковців підкріплені даними статистики про злочинність, котра, значно поширилась на злочинців з вищою освітою, інакше кажучи, освічені, високоінтелектуальні особи вчиняють злочини у сфері службової та професійної діяльності не менше неосвічених [4].

А з іншого боку, має бути вихід із ситуації, який змінить сумну статистику та песимістичні погляди, що склалася в системі освіти, котра, до того ж, знаходиться під потужним впливом глобалізації. Якщо станеться диво, яке науковці убачають у всебічному та гармонійному розвитку особистості, то вона зможе реалізувати власні здібності у власній країні, де соціальна і економічна політика буде спрямована на утвердження культу людини, як головної цінності суспільства. Інакше кажучи, залишається надіятися не лише на диво, а й на певні зміни, що приведуть до всебічного розвитку особистості, які охоплюють також етичне, розумове, естетичне, фізичне та духовне виховання. Тобто, за умов його забезпечення, оптимісти сподіваються отримати нову - моральну людину, спроможну відповідати викликам часу, здатну оволодіти способами практичної діяльності, набувати творчого досвіду і керуватися ціннісними життєвими орієнтирами. Однак, чи втримається вона під впливом так званої глобальної реальності, — покаже час.

Сучасна глобальна освітня система переживає період радикальних перетворень щодо методів, інформаційного змісту та освітнього процесу. Що до особливостей організації освітнього процесу в Україні, то не полишає відчуття ілюзорності того, що освіта дійсно є реальним фактором соціальної мобільності та зростання добробуту. Існує невтішна тенденція, що змушує замислитися: приблизно 65 \% українців, що працюють за спеціальністю, мають бажання змінити професію; більше 30 \% - узагалі не працювали за спеціальністю, а близько $15 \%$ — мали такий досвід, однак змінили роботу. Тобто майже половина жителів України не зна- 
йшли свою нішу в професії, яку опановувала у вищому навчальному закладі [5]. Невтішна статистика і за межами України. Так, за даними ООН з питань освіти, культури та науки більше 200 млн. молодих людей, які закінчили навчальні заклади, не володіють навичками, необхідними для життя та праці [6]. Ігнорувати або зневажати на подібні факти немислимо.

Здається, що лише освітні реформи, лише нова система освіти може задовольнити сучасні вимоги суспільства. Україна прагне наслідувати європейські принципи і стандарти щоб задовольнити очікування населення. Адже конкурентоспроможною стає людина, яка опанувала основи наук, яка володіє новітніми способами сприйняття й передачі інформації, яка практично підготовлена у професійному, мовному та світоглядному плані. Саме в такому ключі розгортаються світові трансформаційні процеси в системі освіти, науки й інформаційних технологій. Частково вони розвиваються і в Україні. Однак, ці зрушення незначні, особливо в гуманітарній сфері, від якої залежать формування духовно-культурних цінностей освіти, які є основою для їх впровадження.

Значних зрушень через виклики глобалізації зазнали стосунки між людьми, а також між державами, причому, вплив позначився на усі сфери життєдіяльності суспільства. Глобалізація розширила і поглибила соціальні зв'язки і культурно-інформаційні контакти між народами і державами. Розширення культурно-інформаційних контактів охопило сферу управління, виробництва, торгівлі, ринку праці, політичні утворення, новостворені суспільні інституції, тобто - всі сфери життєдіяльності сучасної людини. Саме тому науковці наголошують на тому, що особливої уваги потребує не лише професійна виучка, а підготовка особистості з гуманістичним світоглядом, високим рівнем духовної культури та моральності, інакше кажучи, особистості, здатної протистояти технологічному екстремізму, сформованому епохою науково-технічного прогресу. Не людина для техніки, а навпаки - техніка для людини, таким має стати лейтмотив сучасної освіти в сучасному глобалізаційному суспільстві.

Неможливо залишити поза увагою екологічні проблеми, що постають перед людським суспільством і потребують нагального вирішення, адже від їх вирішення залежить збереження біосфери планети та виживання людства. Вимогами часу продиктовані не лише необхідність збереження природи, а й відповідальність за ії збереження, більш того, кожен має долучитися до процесу збереження планети. Від небайдужості усіх залежить майбутнє всієї планети. Людина має усвідомлювати, що збереження природи - це умова ії виживання та виживання людства. На жаль, сировинна, енергетична, продовольча та багато й інших проблем, які притаманні сучасному світу, також мають глобальний характер, оскільки вони охоплюють всю планету і всі основні сфери і життєдіяльності людини,вони зачіпають життєво важливі інтереси всіх держав і народів, виступаючи вагомим чинником взаємозалежності та цілісності світу. Безумовно, надія покладається на освіту, на освічену людину, яка розуміє відповідальність за долю планети, за їі порятунок. Таким чином, від вирішення проблем освіти певною мірою залежить і вирішення проблем екології, і доля людства в цілому.

Глобальний характер екологічної безпеки включає корінний перегляд всіх міжнародних зв'язків і відносин, реалізацію глобально-гуманістичного мислення. Необхідно домагатись встановлення міжнародного екологічного порядку, який би передбачав: введення обов'язкових для всіх країн середніх меж гранично-допустимих концентрацій хімічних речовин і міжнародний контроль за їх дотриманням; міжнародну екологічну експертизу всіх нових крупних проектів природокористування; форми відповідальності країни за знищення екосистем, які відбуваються навіть в межах власних територій; забезпечення адекватною концепцією державами, які експлуатують свої не відновлювані природні ресурси в інтересах світового ринку; створення міжнародного механізму стимулювання, поширення і впровадження чистих технологій. Важлива роль в висвітленні питання глобальних екологічних проблем сучасності відіграє міжнародно-правова охорона навколишнього середовища.

Розвиток мережі Інтернет є одним з пріоритетних напрямів державної політики у сфері інформатизації, задоволення конституційних прав громадян на інформацію, побудови відкритого демократичною суспільства, розвитку підприємництва. Сьогодні Інтернет набув стрімкого розвитку і став не лише засобом комунікації, а й потужнім способом впливу на свідомість користувачів. Його вплив позначився не лише на підвищенні якості освіти, а й на міграції кваліфікованих освітян за кордон. Сумна статистика зумовлює систему вищої освіти змінювати підходи як до освіти, так і до формування фахівців, здатних адаптуватися до конкретних умов праці у власній країні. Можливості Інтернету невичерпні - це і електронна комерція, і віртуальний офіс, і дистанційне навчання, і мультимедійні цифрові ресурси. Кількість користувачів світової спільноти зростає 3 кожним днем. Ніщо не спроможне зупинити цей лавиноподібний процес. Він став невід'ємною частиною людства, її рушійною силою, а тому завдання освіти - використати його можливості для пошуку шляхів вирішення актуальних екологічних, економічних, політичних та ін. проблем, що наявні в нашій країні. Основним завданням Інтернету, на нашу думку, було і залишається трансляція знань, досвіду і моральних цінностей людства, які необхідні для повноцінного життя людини, суспільства, планети. У кожну історичну епоху форми передачі досвіду, обсягу і якості знань, ціннісних орієнтирів дещо змінювалися, а сьогодні, завдяки використанню можливостей Інтернету, цей процес уможливлює кожного користувача не лише бути пасивним спостерігачем, а й активним учасником проектів щодо вирішення глобальних проблем. 
Отже, теорія освіти має виходити з фундаментальних культурних і соціальних підстав свого часу. Тільки так вона може стати дієвою теорією, зможе набути наукового статусу i, за таких умов, зможе продукувати позитивні імплікації для соціальної практики. Як бачимо, освітня теорія потребує проведення статистичного аналізу знань, який має засвідчити наступне: скільки процентів валового національного продукту (ВНП) отримує національна індустрія завдяки застосуванню знать студентів та науковців? На жаль, допоки не існує інформації щодо вищих закладів, які випустили успішних бізнесменів, керівників, політиків, фінансистів тощо. Для виявлення певних закономірностей функціонування вищої школи, спільних для більшості країн, необхідний порівняльний аналіз сучасного стану освіти, а також ретроспективний щодо тенденцій розвитку системи вищої освіти. У такому випадку, слід врахувати наступні аспекти: принципи організації сучасної освіти; структура мережі вищих навчальних закладів (ВН3); особливості прийому; форми контролю знань; забезпечення якості та процедури акредитації; система міжнародного переведення зарахованих дисциплін та визнання освітніх кваліфікацій; організація навчального процесу; система оплати за навчання; система підтримки студентів; система допомоги для навчання за кордоном та працевлаштування; підходи до фінансування; підвищення ролі позабюджетних коштів; здійснення реформ освіти.

Безумовно, стрімкі соціально-економічні зміни в суспільстві вимагають засвоїти найрізноманітніші програми вищої професійної освіти, оволодіти курсом перепідготовки або підвищення кваліфікації, навчання в аспірантурі, докторантурі, ординатурі, брати участь у фундаментальних і прикладних наукових дослідженнях тощо. Адже освіта $є$ пріоритетним напрямом державної політики, отже, слід знати потреби держави, регіонів, галузей економіки у спеціалістах з різними рівнями кваліфікації для створення державної системи навчання талановитої молоді; для розширення можливостей громадян України здобувати вищу освіту за бажаним напрямом. Поза всяким сумнівом, упровадження моделей оцінювання різних рівнів вищої освіти, визначення іiї стандартів, оновлення змісту вищої освіти, впровадження ефективних педагогічних технологій, створення нової системи методичного та інформаційного забезпечення вищої школи, створення інформаційнокомунікативного навчального середовища, формування його загальносистемних програмно-технічних комп'ютерних засобів навчання, комп'ютерних мереж і засобів телекомунікації, організація навчання як безперервної науково-виробничої діяльності при найповнішому використанні наукового потенціалу вищої школи, ефективне використання кадрового потенціалу вищої школи в навчально-виховному процесі та науковій роботі; залучення до педагогічної діяльності у вищих навчальних закладах талановитих наукових працівників академічних та галузевих науково-дослідних інститутів, провідних фахівців народного господарства — усе це, безумовно, сприятиме успішному реформуванню вітчизняної освіти.

Отже, розвиток вищої освіти посідає чільне місце в загальній системі науково-технічних, економічних та соціальних напрямків, а також інших галузей науки. Чинники, від яких залежать якість підготовки спеціалістів, мають такі параметри: розвиток окремих галузей народного господарства та окремих економічних регіонів; зміни демографічної ситуації, матеріальні, трудові, фінансові можливості держави, соціальні наслідки масової підготовки спеціалістів.

Вищі навчальні заклади нашої держави, підпорядковані Міністерству освіти та науки, яке забезпечує розроблення стратегічних напрямів освіти і науки України, утримування певного рівня якості освіти. Очевидно, що все це запроваджується за рахунок коштів державного бюджету. Зміни, або так зване «удосконалення» освіти (йдеться про незалежне оцінювання), ії комерціалізацію (плата за навчання, яка постійно зростає), утримання приміщень тощо, не вирішують сучасні проблеми освіти. Останнім часом в освітній сфері України все частіше фігурують категорії «оцінка якості освіти» або «моніторинг якості освіти», хоча у вітчизняній науковій і спеціальній літературі ці питання висвітлені недостатньо. Певним чином проблема оцінки якості освіти порушується в літературі з питань управління освітою та в публікаціях з питань критеріїв оцінки навчальних знань [6]. До того ж, ідеться здебільшого про оцінку якості освіти через упровадження контрольних процедур і дотримання державних освітніх стандартів або аналізується досвід системи оцінювання знань у західних країнах.

Звичайно, якість освіти - поняття складне. Вона традиційно пов'язується зі змістом і формою навчального процесу, що, як правило, грунтується на кваліфікації та досвіді викладачів. Але швидкоплинність змін, що відбуваються у світі, примушує переглянути усталені погляди. Тому освіта має підготуватись до формування таких рис, як толерантність, сприйняття інших культур, релігій, цінностей, уміння спілкуватися з їх носіями.

Особливої ваги у XXI столітті набуває і такий критерій якості освіти, як ступінь й адекватність природним здібностям кожної людини, особистісно орієнтований характер освіти. Максимально наблизити освіту й виховання до розкриття природних здібностей кожної людини - споконвічна мета і мрія педагогіки. Тому так важливо, щоб освіта була максимально різноманітною, демократичною та особистісно орієнтованою. Отже, поняття «якість освіти» стає все більш системним, багатогранним і реальним.

Нині якість освіти характеризується такими складовими як якість навчально-методичної бази, що передбачає ресурсне забезпечення закладів освіти на належному рівні, залучення до навчального процесу не тільки 
таких якісних, традиційних компонентів, як підручники, а й нових сучасних засобів і методів пізнання, пов'язаних із сучасними технічними можливостями, як якість педагогічних кадрів та професорсько-викладацького складу передбачає переоцінку соціальної ролі вчителя. Сьогодні вчитель і викладач - не тільки абсолютний носій знань, він має виконувати місію духовного поводиря дитини, має стати для неї водночас джерелом авторитетної інформації, майстром навчання способів оволодіння різнопредметною діяльністю, бути організатором пізнавального процесу.

Поза всяким сумнівом, що вимоги до якості освіти та умов і принципів її здобуття, визначені у відповідному розділі Національної доктрини розвитку освіти [7], в основному, акцентують увагу на модернізацію системи освіти, що спрямована на забезпечення їі якості відповідно до найновіших досягнень вітчизняної та світової науки, культури й соціальної політики. По-друге, якість освіти характеризується як національний пріоритет і передумова виконання міжнародних норм та національного законодавства щодо реалізації прав громадян на здобуття освіти. Підкреслюється також, що якість освіти визначається на основі вимог державних стандартів (освіти) та оцінкою громадськістю освітніх послуг. По-четверте, вказується, що забезпеченню якості освіти підпорядковані матеріальні, фінансові, кадрові й науково-методичні ресурси суспільства, державна політика в галузі освіти, i, нарешті, звичайно, зазначається, що висока якість освіти передбачає органічний взаємозв'язок освіти і науки, педагогічної теорії й практики [8]. На жаль, законодавство явно відстає від потреб життя.

Безумовно, визначення критеріїв та показників якості освіти залишається однією з центральних проблем. Традиційно на території колишнього СРСР, у тому числі і в Україні, розвиток вищої школи оцінюють за кількома універсальними індикаторами, а саме - чисельність студентів у абсолютному вимірі, кількість студентів на 10 тис населення, кількість студентів, що навчаються за рахунок бюджету і на контрактній основі, чисельність прийнятих на перший курс та випущених фахівців, чисельність викладацького складу тощо. Розвиток середньої освіти традиційно вимірюється тільки через показники оцінювання успішності учнів 3 різних предметів. Щоденне внутрішнє оцінювання складається з «нормативного» і «критерійного» компонентів, досягнення кожного учня оцінюється щодо певної норми, за яку приймаються усереднені досягнення групи чи класу.

Нині оцінювання якості освіти належить винятково державним структурам, освітяни змушені доводити свою необхідність у галузі послуг не лише перед державними органами, а й перед суспільством, перед приватними особами, які є споживачами цих послуг, зрештою - перед світовою спільнотою. На жаль, принципово неможливо керувати складною системою оцінювання освіти та їі якості тільки засобами державного контролю і регулювання. Висока міра залежності освітніх закладів від державних органів управління призводить до того, що вони сприймаються тільки як органи обмеження та контролю, від яких залежить доля закладу. Тому в освітніх закладах виникає бажання за будь-яких умов догодити, пристосуватися до вимог державних органів управління, що призводить до знеособлення освітніх закладів.

Взагалі будь-яка оцінка якості є відносною, тому що залежить від безлічі об’єктивних і суб’єктивних факторів, вибору базису системи оцінок. Тому жодній організації не може належати монопольне право на єдино правильну оцінку якості, в тому числі у сфері освіти. Необхідне залучення представництв 3 громадської оцінки, які б доповнювали одна одну. Це можуть бути громадські об’єднання з представників зацікавлених кіл і міжнародні організації. Громадська оцінка якості освіти має бути відкритою, прозорою та публічною і враховувати різні критерії оцінювання - 3 погляду систем державного управління, місцевого самоврядування, професійних груп, батьків та учнів, корпорацій та бізнесових кіл і т. ін., тобто потрібно забезпечувати доступ їх до оцінювання якості освіти. Нині навіть доступ до офіційної статистики утруднений, а крім того, статистика не надає усіх, вкрай необхідних для оцінювання якості освіти, показників. Так, базового показника якості освіти зовсім немає в сучасних українських системах оцінювання.

Громадська оцінка якості середньої і вищої освіти сьогодні використовується в багатьох країнах. Наприклад, у європейських країнах альтернативним методом оцінювання успішності учнів у середній школі $є$ зовнішнє оцінювання, яке дає змогу одержати дані щодо рівня знань учнів на регіональному або національному рівнях [9]. Положення, висвітлені в Національній доктрині розвитку освіти України у ХХІ столітті, визначили необхідність формування нової якості освіти як одне з найважливіших завдань освітньої політики. Розвиток системи підготовки фахівців міжнародного рівня представлено як проблему, розв'язання якої визначає інноваційну діяльність нашого суспільства в галузях економічної та науково-технічної співпраці. Перспективи входження України не лише до міжнародного економічного простору, а й вихід на рівень міжнародної взаємодії в галузі вищої освіти потребують глибшого осмислення проблем підготовки фахівців, зокрема фахівців з маркетингу, освіта і кваліфікація яких зможуть забезпечити конкурентоспроможність наших досягнень на світовому ринку.

Проблема оцінювання якості освіти існувала завжди, і тільки в останні роки почали застосовуватися системний комплексний підхід що до її вирішення. Відповідно до вимог ЮНЕСКО, є три чинники освітньої діяльності, що найбільш істотно впливають на якість вищої освіти [9]. По-перше, це якість персоналу, що передбачає 
високий рівень академічної кваліфікації викладачів і наукових співробітників ВНЗ, та якість освітніх програм, що забезпечується сполученням відповідного рівня викладання та проведення досліджень, їхньою відповідністю суспільному попиту. По-друге, це якість підготовки студентів, що в умовах, коли вища освіта набула масового характеру, може бути досягнута тільки шляхом диверсифікації освітніх програм, подолання багатопланового розриву, що існує між середньою і вищою освітою, і підвищення ролі механізмів учбово-професійної орієнтації та мотивації молоді. I, нарешті, це якість інфраструктури та «фізичного навчального середовища» вищих навчальних закладів, яка охоплює «всю сукупність умов» їхнього функціонування, зокрема комп'ютерні мережі та сучасні бібліотеки, що може бути забезпечена шляхом відповідного фінансування, можливого тільки у разі збереження державного підходу до вищої освіти як до загальнонаціонального пріоритету.

ВН3, зі свого боку, дедалі більше залежать від бачення напрямків зміни в змісті і конфігураціях професійного знання. Вона визначається дослідним складом розуму, готового сприймати і прогнозувати глибинні зміни парадигмального типу, проникати в принципово невідоме, тобто таке незвідане, яке володіє системною непередбачуваністю як неможливістю отримання просто логічним продовженням усталеної конфігурації знань. Динамічна компетентність створюється за допомогою дослідного навчання, яке відноситься до знання як до непередбаченої події. Таке навчання становить горизонт розвитку сучасної освіти. Людська творчість — це рушійна сила економічного зростання і розвитку нового суспільства. Як уже відзначалось, економічний аспект творчості, безумовно, сприяє підприємництву, інноваційному економічному зростанню, створенню культурної продукції, наукових винаходів, технологічних нововведень. Інакше кажучи, освіта знаходиться в центрі зв'язку економіки і творчості, проте не вистачає досліджень в сфері теоретичного розуміння творчості в освіті.

Висновки. Суспільство знань як особливий соціальний простір сучасного суспільства формується протягом тривалого часу. Його центрами кристалізації $€$ нова система поділу праці, інноваційні інститути розвитку, освітні організації, які виховують працівника знань, проблеми суспільного розвитку. Соціальне замовлення на підготовку працівника знань, здатного бути продуктивним в умовах динамічно мінливого знання і техніко-технологічного оточення, є одним з головних викликів сучасної освіти. Така система освіти повинна базуватись на ідеї випереджаючого навчання і принципі безперервної освіти для працівника знань. Творчий характер навчання визначає здатність працівника знань, учнів та студентів до соціальних і техніко-технологічних інновацій, а дослідження формують їх динамічну компетентність і соціально-економічну продуктивність.

\section{Література}

1. Иммануил Кант. Критика чистого разума / пер. с нем.; предисл. И. Евлампиева. М. : Эксмо; СПб.: Мидгард, 2007. $1120 \mathrm{c}$.

2. Doll W.E. A Post-modern Perspective on Curriculum. New York and London: Teacher College Press, Columbia University, 1993. $215 \mathrm{p}$.

3. Підготовка наукової еліти - пріоритет державної освітньої політики / Бар'яхтар В. Г., Горобець Ю. І., Данилович А. В., Порєв С. М. // Вісник АПН України. Педагогіка і психологія. 2006. № 3 (52). С. $49-54$.

4. Савчук Т. І. Про виявлення економічних злочинів // Вісник Харківського національного університету внутрішніх справ. 2010. № 1 (48).

5. I. М. Кукса, Т. О. Пєтухова. Креативна економіка як елемент інноваційної та стійкої стратегії розвитку України. URL: http://www.economy.nayka.com.ua/?op=1\&z=6555.

6. Рівень освіти населення у відповідних вікових групах // Ukrstat.org - публікація документів Державної служби Статистики України. URL: http://ukrstat.org/uk/operativ/operativ2010/gdn/sdh/dod_06.htm.

7. Національна доктрина розвитку освіти України у XXI столітті / Міністерство освіти і науки України, Академія педагогічних наук України. URL: http://www univd.edu.ua.

8. Про Національну доктрину розвитку освіти. URL: http://zakon.rada.gov.ua/laws/show/347/2002.

9. Всесвітня конференція з вищої освіти — 2009: «Нова динаміка вищої освіти і науки для соціальної зміни і розвитку». URL: https://zakon.rada.gov.ua/laws/show/952_011.

10. Співробітництво України та ЮНЕСКО. URL: https:/unesco.mfa.gov.ua/ua/ukraine-unesco/cooperation . 